\title{
Expression and localization of vascular endothelial growth factor and its receptors in pig corpora lutea during the oestrous cycle
}

\author{
U. Boonyaprakob ${ }^{1}$, J. E. Gadsby ${ }^{2}$, V. Hedgpeth ${ }^{2}$, P. Routh ${ }^{1}$ and G. W. Almond ${ }^{1 *}$ \\ ${ }^{1}$ Department of Farm Animal Health and Resource Management and ${ }^{2}$ Department of Anatomy, \\ Physiological Sciences and Radiology, College of Veterinary Medicine, North Carolina State University, \\ 4700 Hillsborough Street, Raleigh, NC 27606, USA
}

\begin{abstract}
Expression and localization of mRNAs for vascular endothelial growth factor (VEGF), VEGF receptor 1 (FIt) and VEGF receptor 2 (KDR) (VEGFR-1 and VEGFR-2, respectively) were investigated in pig corpora lutea. Northern blot analysis of total RNA indicated hybridization of pig VEGF, VEGFR-1 and VEGFR-2 cDNA probes to mRNA transcripts of approximately $3.9,7.0$ and $5.0 \mathrm{~kb}$, respectively. The expression of mRNAs for VEGF and its receptors during the luteal phase (days 4, 7, 10, 13 and 15 after the onset of oestrus) were assessed by northern blot analysis, and hybridization signals were normalized to expression of pig $18 S$ rRNA. Relative hybridization signals of expression of VEGF mRNA appeared to be constant; however, expression of VEGFR-1 mRNA was low on day 4, increased on day 7 , and was higher on days 10, 13 and $15(P<0.05$, compared
\end{abstract}

with day 4). In contrast, no changes in expression of mRNA for VEGFR-2 were evident on days 4-13, but a decrease was detected $(P<0.05)$ at day 15 . In situ hybridization revealed that VEGF mRNA was localized predominantly in large luteal cells, whereas both VEGFR-1 and VEGFR-2 were localized to small cells. These data indicate that the VEGF system may be involved in the regulation of luteal vasculature throughout the lifespan of the corpus luteum. Although the expression of VEGF mRNA was unchanged during the luteal phase, variations in the expression of VEGFR-1 and VEGFR-2 mRNAs indicate that differential regulation of expression of the VEGF receptors may play a role in the control of VEGF-mediated vascular growth at different phases of development and maturation of the pig corpus luteum.

\section{Introduction}

The corpus luteum has an extensive capillary network and endothelial cells contribute to approximately 50\% of the total luteal cell composition (Farin et al., 1986; Lei et al., 1991). Rapid proliferation and differentiation of vascular endothelial cells from pre-existing vessels to form new capillaries, also known as angiogenesis, is a profound aspect of luteal development (Augustin et al., 1995). Several molecules have been implicated as mediators of angiogenesis of the corpus luteum; however, vascular endothelial growth factor (VEGF) appears to play a pivotal role in the regulation of vascular growth in the corpus luteum for several species (Ferrara et al., 1998; Fraser et al., 2000; Wulff et al., 2001; Zimmermann et al., 2001). Interruption of VEGF function using soluble truncated VEGF receptor 1 (VEGFR-1) (Ferrara et al., 1998; Wulff et al., 2001), antiVEGF (Fraser et al., 2000) or anti-VEGFR-2 antibody (Zimmermann et al., 2001) inhibited development and

${ }^{*}$ Correspondence

Email: glen_almond@ncsu.edu function of the corpus luteum, and was associated with suppression of luteal angiogenesis. There is growing evidence to support the concept that VEGF is required for the maintenance of luteal vasculature during the midluteal phase of the oestrous cycle (Dickson et al., 2001). Thus, VEGF is probably a potent regulator of vascular growth and maintenance in the corpus luteum.

VEGF is a specific mitogen for endothelial cells (Leung et al., 1989). Five human VEGF isoforms have been identified; the predominant isoforms are $\mathrm{VEGF}_{121}$ and VEGF $_{165}$ (Neufeld et al., 1999). Luteal tissues from various species, including rats (Phillips et al., 1990), monkeys (Ravindranath et al., 1992), humans (Sugino et al., 2000), cattle (Berisha et al., 2000) and sheep (Redmer et al., 1996) have been found to be a source of VEGF. In most species, two VEGF transcripts, corresponding in length to $\mathrm{VEGF}_{120 / 121}$ and $\mathrm{VEGF}_{164 / 165}$, are present in the corpus luteum (Redmer et al., 1996; Berisha et al., 2000; Sugino et al., 2000), and an additional larger transcript $\mathrm{VEGF}_{188}$ has been found in ovine corpora lutea (Redmer et al., 1996). Several subpopulations of luteal cell, including granulosa-lutein cells and thecalutein cells, produce VEGF (Kamat et al., 1995). VEGF 
acts through two phosphotyrosine kinase receptors on endothelial cells, namely the VEGFR-1 or 'fms-like tyrosine kinase' (Flt-1) and the VEGFR-2 or 'kinase insert domain-containing receptor' (KDR) (Neufeld et al., 1999). Previous studies have revealed that these receptors are expressed in human (Sugino et al., 2000) and bovine (Berisha et al., 2000) luteal tissues. No data are currently available for pig corpora lutea.

In pigs, previous studies have revealed the presence of two isoforms of VEGF $\left(\mathrm{VEGF}_{120}(1.7 \mathrm{~kb})\right.$ and $\mathrm{VEGF}_{164}$ $(3.9 \mathrm{~kb}))$ from pig heart (Sharma et al., 1995) and follicular tissues (Barboni et al., 2000; Shimizu et al., 2002). Expression of VEGF mRNA was localized to both the granulosa and theca compartments of the follicle (Barboni et al., 2000). In vivo studies have shown that administration of eCG increased expression of VEGF mRNA in the granulosa compartment (Shimizu et al., 2002) and the amount of VEGF protein in follicular fluid (Barboni et al., 2000). In contrast, no changes were observed in the theca compartment, in which expression of VEGF mRNA was low. Administration of hCG disrupted VEGF production within the granulosa compartment and follicular fluid, but had no effect on expression of thecal VEGF, which remained low (Barboni et al., 2000). The presence of angiogenic factors (presumably basic fibroblast growth factor (bFGF) or VEGF-like molecules) has been reported in pig corpora lutea (Ricke et al., 1995). However, there have been few reports describing the expression of VEGF and its receptors in pig corpora lutea. Thus, in the present study, the expression and localization of VEGF, VEGFR-1 and VEGFR-2 mRNAs were examined at different stages of the oestrous cycle to determine the physiological role of the VEGF system in angiogenesis of pig corpora lutea.

\section{Materials and Methods}

\section{Materials}

Pig cDNA for $18 \mathrm{~S}$ rRNA was generously provided by R. McNeel (Department of Pediatrics, Baylor College of Medicine, Houston, TX) (Ding et al., 1999). PG600 ${ }^{\circledR}$ was obtained from Intervet Inc. (Millsboro, DE). Euthasol was purchased from Diamond Animal Health Inc. (Des Moines, IA). Other materials and reagents included: ${ }^{35}[S]$ UTP $\left(\right.$ NEN ${ }^{\circledR}$ Life Science Products Inc., Boston, MA); ${ }^{32}[\mathrm{P}] \mathrm{dCTP}$ (ICN Pharmaceuticals Inc., Costa Mesa, CA); Denhart solution (USB Scientific, Cleveland, OH); MAXIscript SP6/T7 Kit (Ambion Inc., Austin, TX); Qiagen ${ }^{\circledR}$ Plasmid MidiKit (Qiagen Inc., Valencia, CA); Zeta-Probe ${ }^{\circledR}$ GT blotting membrane (Bio-Rad, Richmond, CA); primers (Genosys Biotechnologies Inc., The Woodlands, TX); collagenase type IV (Worthington Biochemical Corp., Freehold, NJ); SuperScript ${ }^{T M}$ II RNase $\mathrm{H}$ reverse transcriptase and random primers DNA labelling system (Gibco-BRL Life Technologies, Grand Island, NY); autoradiography emulsion (Eastman Kodak,
Rochester, NY); Ultrafree-DA for DNA extraction from agarose (Millipore Corp., Bedford, MA); PGEM $^{\circledR}-T_{\text {T }}$ Easy vector System II, oligodeoxythymidine (oligo $[\mathrm{dT}]_{12-18}$ ) $\left(0.5 \mu \mathrm{g} \mathrm{I}^{-1}\right)$, JM109 competent cells, RNase inhibitor, RNA molecular weight marker and dithiothreitol (Promega, Madison, WI); Taq DNA polymerase, Quick Spin columns G-50 Sephadex, sperm DNA, yeast total RNA, tRNA, deionized formamide and ribonuclease A (Roche, Indianapolis, IN); and paraformaldehyde, Tri-Reagent, triethanolamine, acetic anhydride, dextran sulphate, Hank's balanced salt solution (HBSS; without calcium and magnesium), bovine serum albumin (BSA; fraction $V$ ), Hepes, hyaluronidase (type $V$ from ovine testis), deoxyribonuclease (DNase type I from bovine pancreas), penicillin-streptomycin, gentamycin and 0.2 10.0 kb RNA marker (Sigma Chemical Co., St Louis, MO). All other materials and chemicals were purchased from Fisher Scientific (Pittsburgh, PA) unless specified otherwise.

\section{Animals and tissues}

The North Carolina State University Institutional Animal Care and Use Committee approved the experimental protocol for use of animals. Gilts $(n=20$; Yorkshire $\times$ Landrace $\times$ Chester White; aged 170-180 days) were treated with $\mathrm{PG} 600^{\circledR}$ (400 iu eCG and 200 hCG). The onset of oestrus was checked twice a day with a mature boar starting 2 days after i.m. injection with PG600 ${ }^{\circledR}$. The first day of standing oestrus was classified as day 0 of the oestrous cycle. Animals $(n=3$ per day, total $n=15$ ) were killed at days 4, 7, 10, 13 and 15. Five of the initial 20 animals were discarded from the study as two did not show signs of oestrus and three failed to ovulate. The ovaries were collected immediately after death, and the corpora lutea were processed and stored for in situ hybridization, RNA extraction and dissociation for mixed luteal cell preparations (Boonyaprakob et al., 2003). In addition to the corpora lutea, ovarian tissue with follicles was collected for in situ hybridization. On the basis of previous reports of expression of VEGF and VEGF receptor mRNA in pig follicles (Barboni et al., 2000; Shimizu et al., 2002), the additional tissue was included for comparison, and to provide an indication of the mRNA expression in granulosa and thecal layers before luteinization.

For each animal, two corpora lutea were embedded in OCT medium on dry ice, three or four corpora lutea were snap-frozen in liquid nitrogen and stored at $-80^{\circ} \mathrm{C}$ until RNA extraction was performed, and the remaining corpora lutea were dissected into small pieces for enzymatic dissociation in Hank's medium containing $1 \%(\mathrm{w} / \mathrm{v}) \mathrm{BSA}, 0.1 \%(\mathrm{w} / \mathrm{v})$ hyaluronidase, $0.1 \%(\mathrm{w} / \mathrm{v})$ collagenase and $0.006 \%(\mathrm{w} / \mathrm{v})$ DNase as described by Gadsby and Earnest (1994). After dissociation and filtration through nylon mesh (120 $\mu \mathrm{m}$ pores), the dispersed cells were suspended in Hank's medium with $0.1 \%$ 
BSA, 25 mmol Hepes $\mathrm{I}^{-1}$ and $25 \mathrm{mmol} \mathrm{NaHCO}_{3} \mathrm{I}^{-1}$. On the basis of Trypan blue exclusion, the dispersed cells had $>80 \%$ viability. Conventional cytocentrifugation or cytospin (Fitzgerald and Hosking, 1982) were used to make microscope slide preparations with mixed luteal cells (20 000 large luteal cells per slide). The slide cell preparations were fixed in $4 \%(\mathrm{w} / \mathrm{v})$ paraformadehydePBS, dehydrated through a graded ethanol series and stored at $-80^{\circ} \mathrm{C}$. For in situ hybridization studies, frozen corpora lutea in OCT were cut into sections $(8 \mu \mathrm{m}$ thickness) using a cryostat, mounted on Superfrost/Plus slides and stored at $-80^{\circ} \mathrm{C}$.

\section{Cloning and sequencing of pig VEGF, VEGFR-1 and VEGFR-2 CDNA}

The primer pairs for VEGF, VEGFR-1 and VEGFR-2 were designed based on pig CDNA sequences published in GenBank. For VEGF primers, nucleotide positions were based on GenBank accession number X81380. For VEGFR-1 and VEGFR-2 primers, nucleotide positions were based on GenBank accession numbers AJ245445 and AJ245446, respectively. The VEGF primer sequences were 5'-AGCTACTGCCGTCCAATCGAG-3' (sense) and 5'-TGTCACATCTGCAAGTACGTTCG-3' (antisense), corresponding to nucleotides $145-165$ and 559-537 of pig VEGF CDNA, respectively. The VEGFR-1 primer sequences were 5'-CTCCTTAGGAGGGTCCCCGTA-3' (sense) and 5'-AGTGGAGTACGTGAAGCCGCT-3' (antisense), corresponding to nucleotides 49-69 and 328-308 of pig VEGFR-1 cDNA, respectively. The VEGFR-2 primer sequences were 5'-GAGTGGCTCTGAGGAACGAGTG$3^{\prime}$ (sense) and 5'-AACAAACCTCTTTTCTGGATACCTCG$3^{\prime}$ (antisense), corresponding to nucleotides 25-46 and 337-312 of pig VEGFR-2 cDNA, respectively.

Total RNA was extracted from frozen pig corpora lutea using TriReagent following the manufacturer's recommendations. Each cDNA was synthesized using a RTPCR. In brief, oligo d(T)15 primers were used to reverse transcribe pig corpus luteum total RNA (Superscript ${ }^{\mathrm{TM}} \mathrm{II}$ ), and the PCR reaction was conducted using a sense and antisense primer pair specific to pig VEGF, VEGFR-1 or VEGFR-2, and with the following conditions: initial denaturation for $1 \mathrm{~min}$ at $94^{\circ} \mathrm{C}$ followed by 35 cycles of $1 \mathrm{~min}$ at $94^{\circ} \mathrm{C} ; 1 \mathrm{~min}$ at $55^{\circ} \mathrm{C}$ and $1 \mathrm{~min}$ at $72^{\circ} \mathrm{C}$; and a final extension of $7 \mathrm{~min}$ at $72^{\circ} \mathrm{C}$. One specific band for each PCR product (VEGF: approximately $415 \mathrm{bp}$; VEGFR-1: approximately $280 \mathrm{bp}$; VEGFR-2: approximately $313 \mathrm{bp}$ ) was isolated, cloned into the pGEM-T Easy vector, and sequenced at the lowa State University DNA Sequencing and Synthesis Facility (lowa State University, Ames, IA). After verification that it was a correct insert, each complementary DNA (cDNA) clone was subsequently used as a template for radiolabelled probe synthesis for the northern blot analyses and in situ hybridization.

\section{Preparation of pig VEGF, VEGFRs and $18 S$ rRNA probes}

Pig VEGF, VEGFR-1, VEGFR-2 and $18 \mathrm{~S}$ cDNA were linearized with appropriate restriction enzymes. For northern blot hybridization, EcoRI was used to excise the sequences from the plasmids except for $18 \mathrm{~S}$ cDNA, for which Notl and EcoRI were used. The linearized templates were purified by gel electrolysis and isolated by a DNA extraction column (Ultrafree-DA). The cDNA probes were prepared using the random primer DNA labelling system and $\left.{ }^{32} \mathrm{P}\right]$ deoxycytidine $5^{\prime}$-triphosphate $\left(3000 \mathrm{Ci} \mathrm{mmol}^{-1}\right)$. For in situ hybridization, each cDNA template was linearized using Pstl or $\mathrm{Ncol}$ for synthesis of sense or antisense cRNA probe, respectively. After purification and isolation, sense and antisense cRNA probes were prepared using an RNA transcription kit (MAXIscript SP6/T7 Kit) and labelled with ${ }^{35}$ S]-UTP. Each radiolabelled cRNA probe was filtered to remove unincorporated nucleotides using Sephadex G50-Quick spin columns.

\section{$R N A$ preparation and northern blot analysis}

Total cellular RNA was prepared by the method of Chomczynski and Sacchi (1987). Frozen corpora lutea were weighed, crushed in liquid nitrogen and homogenized in $10 \%(\mathrm{w} / \mathrm{v})$ Tri-Reagent. Extraction of the RNA was performed according to the manufacturer's protocol. The purified RNA was resuspended in RNase-free water and concentration was measured by spectrophotometry at $260 \mathrm{~nm}$. The northern blot procedures used in this study were as previously described by Nicholson et al. (1999) and modified in our laboratory by Boonyaprakob et al. (2003). In brief, samples of total RNA (20 $\mu \mathrm{g}$ of each sample) were denatured and then separated on $1 \%(\mathrm{w} / \mathrm{v})$ agarose gels. The gels were stained with ethidium bromide after electrophoresis and the ribosomal RNA bands were visualized under UV illumination to ensure the integrity of the RNA samples. The size of the mRNA transcripts was calculated on the basis of molecular size markers run on the same gel after visualization by ethidium bromide staining. Gels were transferred to nylon membranes overnight using the TurboblotterTM rapid downward transfer system (Schleicher and Schuell, Keene, $\mathrm{NH}$ ). The blotted membrane was rinsed and dried at $80^{\circ} \mathrm{C}$ for $60 \mathrm{~min}$. The membranes were prehybridized for $30 \mathrm{~min}$ and the section was placed in new prehybridization solution with denatured DNA probe $(2.5 \times$ $10^{9}$ c.p.m. $\mathrm{ml}^{-1}$; total volume $5 \mathrm{ml}$ ) and the hybridization was continued overnight. The membrane was washed twice with $0.15 \times$ SSC containing $0.1 \%(\mathrm{w} / \mathrm{v})$ SDS and $1 \mathrm{mmol}^{\mathrm{EDTA} \mathrm{I}}{ }^{-1}, \mathrm{pH} 8.0$ at room temperature for $30 \mathrm{~min}$, and twice with $20 \mathrm{mmol} \mathrm{NaHPO}_{4} \mathrm{I}^{-1}$, $1 \%(\mathrm{w} / \mathrm{v}) \mathrm{SDS}, 1 \mathrm{mmol} \mathrm{EDTA} \mathrm{I}^{-1}, \mathrm{pH} 8.0$ at $65^{\circ} \mathrm{C}$ for ${ }^{-}-$ $15 \mathrm{~min}$ (the washing condition was optimized for each probe). After a final wash, the membrane was covered with saran wrap and exposed to a phosphorimaging 
screen (Molecular Dynamics, Sunnyvale, CA) at room temperature for $8-10 \mathrm{~h}$ depending on the riboprobes. Subsequently, the blots were stripped in a shaking chamber containing a boiling solution of $0.15 \times$ SSC and $0.5 \%(\mathrm{w} / \mathrm{v})$ SDS for $15 \mathrm{~min}$, and then boiling water for $15 \mathrm{~min}$. The membrane was prehybridized as before and hybridized with the pig $18 \mathrm{~S}$ rRNA probe. The blot was washed and exposed to a phosphorimaging screen for $15 \mathrm{~min}$. Quantification of hybridization signals was obtained by phosphorimage analysis using ImageQuant software (Molecular Dynamics, Sunnyvale, CA). A ${ }^{32} \mathrm{P}$ labelled probe for pig $18 \mathrm{~S}$ rRNA was used as a control to correct for the amount of RNA sample loading. The values were reported as arbitrary units above background and were normalized to the signal of $18 \mathrm{~S}$ rRNA in each lane by expressing each value as a ratio to the $18 \mathrm{~S}$ signal. A pool of RNA was made by combining purified RNA extracted from the day 4-15 corpora lutea. The pooled RNA was used as an internal control between each blot. The intensities for VEGF, VEGFR-1 and VEGFR-2 were adjusted according to the difference between the signals of the pooled RNA samples among blots. The signal values for $18 \mathrm{~S}$ were adjusted by calculating the difference of intensities between blots for the pooled sample, and then used to adjust the signals between blots. Therefore, the VEGF, VEGFR-1, VEGFR-2 and 18S signals were adjusted before determining the RNA:18S ratios.

\section{In situ hybridization}

In situ hybridization was performed as described by Wandji et al. (1998) with minor modifications (Boonyaprakob et al., 2003). After fixation in 4\% paraformadehyde-PBS, processing of the tissue slides included dehydration, rehydration, incubation in prehybridization buffer and incubation with radiolabelled cRNA probe $\left(4.5 \times 10^{10}\right.$ c.p.m. $\left.\mathrm{ml}^{-1}\right)$ in hybridization buffer. After hybridization, unhybridized single-strand probes were degraded with ribonuclease $\mathrm{A}\left(100 \mu \mathrm{g} \mathrm{ml}^{-1}\right)$ in digestion buffer, washed twice with digestion buffer (no ribonuclease) and washed in $0.25 \times$ SSC at 55$60^{\circ} \mathrm{C}$ for $2 \mathrm{~h}$. After washing, the slides were dehydrated through a graded ethanol series, dried and exposed to autoradiographic film (Kodak BiomaxMR; Eastman Kodak Co., Rochester, NY) to evaluate the intensity of hybridization signals. The slides were dipped in liquid emulsion (Kodak NTB2) and exposed for 3 weeks at room temperature. The emulsion-coated slides were developed in Kodak-D19 developer and fixed according to the manufacturer's recommendations. The slides were counterstained with haematoxylin-eosin and examined under a light microscope.

\section{Blood samples and hormone assays}

Blood samples were collected from each animal before administration of $\mathrm{PG} 600^{\circledR}$ and before they were killed to measure serum progesterone concentrations. Serum was collected after centrifugation at $1500 \boldsymbol{g}$ for $15 \mathrm{~min}$ and was stored at $-20^{\circ} \mathrm{C}$ until assayed for progesterone. Progesterone was quantified using commercial radioimmunoassay kits as described by Feng and Almond (1996). All samples were assayed in duplicate and $100 \mu \mathrm{l}$ serum was used in each replicate. The sensitivity of the assay was $100 \mathrm{pg} \mathrm{ml}^{-1}$, and the intraassay coefficients of variation for both high $\left(18 \mathrm{ng} \mathrm{ml}^{-1}\right)$ and low $\left(0.3 \mathrm{ng} \mathrm{m}^{-1}\right)$ progesterone reference sera were $<5 \%$.

\section{Statistical analysis}

Northern blot data were expressed as the ratio of the signal intensity for each probe to $18 \mathrm{~S}$ rRNA and are shown as mean arbitrary units \pm SEM. The mean for a specific day represents luteal mRNA expression from three animals. The data were initially analysed for heterogeneity of variance using the univariate procedure (SAS, 1988). As the data were homogeneous, they were examined by an ANOVA using the general linear model (GLM) procedure (SAS, 1988). Differences in means were compared by Duncan's multiple range tests when a significant $F$ statistic $(P<0.01)$ was obtained.

\section{Results}

\section{Serum progesterone concentrations}

Serum progesterone concentrations were $<0.2 \mathrm{ng}$ $\mathrm{ml}^{-1}$ in all animals before the administration of $\mathrm{PG} 600^{\circledR}$. After $\mathrm{PG} 600^{\circledR}$ administration, serum progesterone concentrations increased with increasing age of the corpus luteum. Serum progesterone concentrations at day 4 (10.4 $\pm 2.09 \mathrm{ng} \mathrm{ml}^{-1}, n=11$ corpora lutea per pig) were lower $(P<0.05)$ than those at day $10(39.9 \pm 4.1 \mathrm{ng}$ $\mathrm{ml}^{-1}, n=12$ corpora lutea per pig) and day 13 (86.7 \pm $16.0 \mathrm{ng} \mathrm{ml}^{-1}, \quad n=21$ corpora lutea per pig). Serum progesterone concentrations at day $7(22.6 \pm 3.3 \mathrm{ng}$ $\mathrm{ml}^{-1}, n=11$ corpora lutea per pig) did not differ from those on any other day, except for day 13. The concentrations of serum progesterone obtained on day 15 (46.9 $\pm 5.1 \mathrm{ng} \mathrm{ml}^{-1}, n=12$ corpora lutea per pig) were not different from concentrations on days 7 and 10 , indicating that the corpora lutea remained functionally active on this day.

\section{Northern blot analyses}

Northern blot analysis was performed on total RNA prepared from pig corpora lutea collected during different stages of the oestrous cycle. When the ${ }^{32}$ P-labelled antisense VEGF probe was used for hybridization, the RNA from all stages showed a strong positive band of approximately $3.9 \mathrm{~kb}$ (Fig. 1a). Expression of the pig 
Day after onset of oestrus

(a)

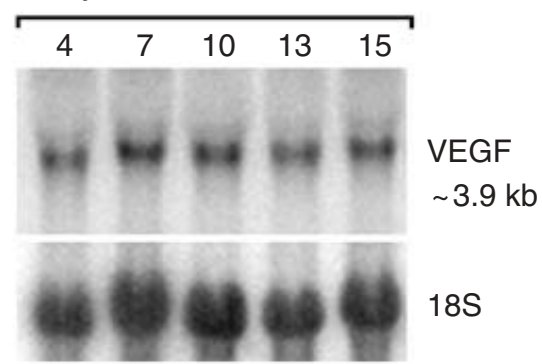

(b)

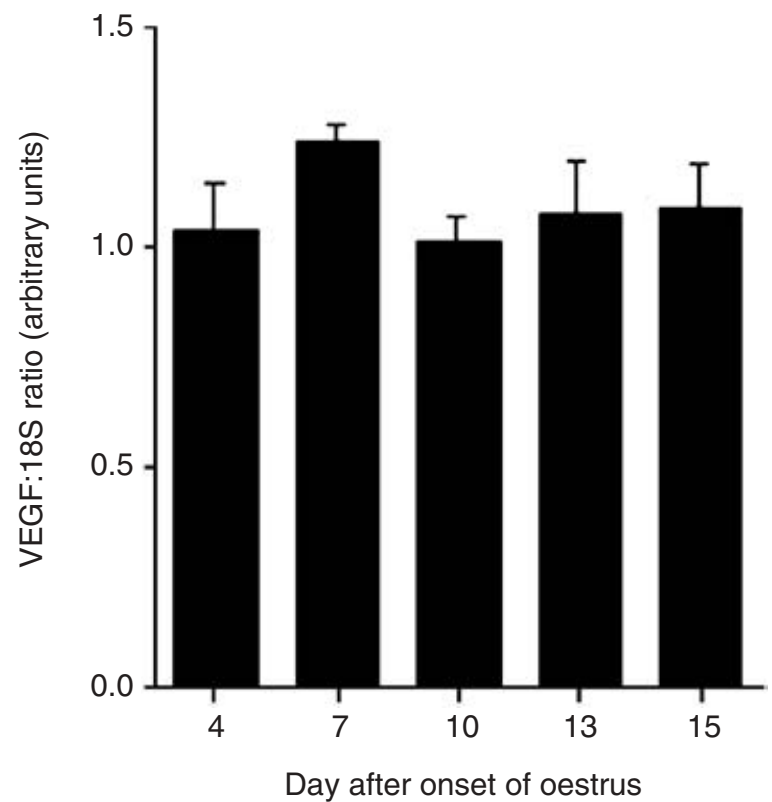

Fig. 1. Expression of vascular endothelial growth factor (VEGF) mRNA in pig corpora lutea obtained at days 4, 7, 10, 13 and 15 after the onset of oestrus. (a) Representative autoradiograph of northern blot analysis for VEGF mRNA (top) and 18S rRNA (bottom). VEGF mRNA size was approximately $3.9 \mathrm{~kb}$. (b) The relative amounts of VEGF mRNA to $18 \mathrm{~S}$ rRNA (arbitrary units \pm SEM; $n=3$ animals day ${ }^{-1}$ ). No differences were observed between days.

VEGF transcript in the corpus luteum was detected throughout the cycle; however, the VEGF:18S ratio did not differ significantly between days (Fig. 1b).

Both VEGFR-1 and VEGFR-2 transcripts were also detected in pig corpora lutea (Figs $2 \mathrm{a}$ and $3 \mathrm{a}$ ). A single transcript for VEGFR-1 mRNA was observed at approximately $7 \mathrm{~kb}$. Expression of VEGFR-1 was found throughout the luteal phase; however, relative expression of VEGFR-1 in the corpus luteum was low at the early stage and the expression of VEGFR-1 mRNA increased with age of the corpus luteum. The VEGFR$1: 18 \mathrm{~S}$ ratio increased gradually from $0.74 \pm 0.11$ at day 4 to $1.43 \pm 0.19$ (arbitrary units) at day 15 (Fig. 2b). A single transcript of VEGFR-2 mRNA was detected at approximately $5.9 \mathrm{~kb}$ in pig corpus luteum (Fig. 3a). The relative expression of VEGFR-2 mRNA was similar on (a)

Day after onset of oestrus

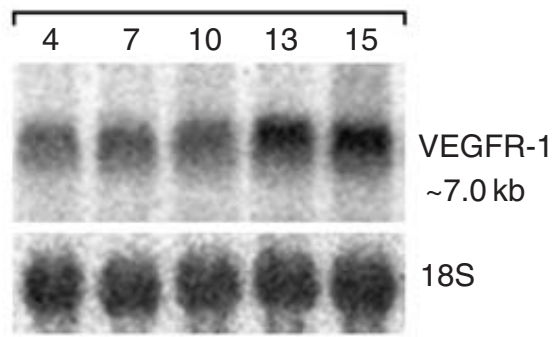

(b)

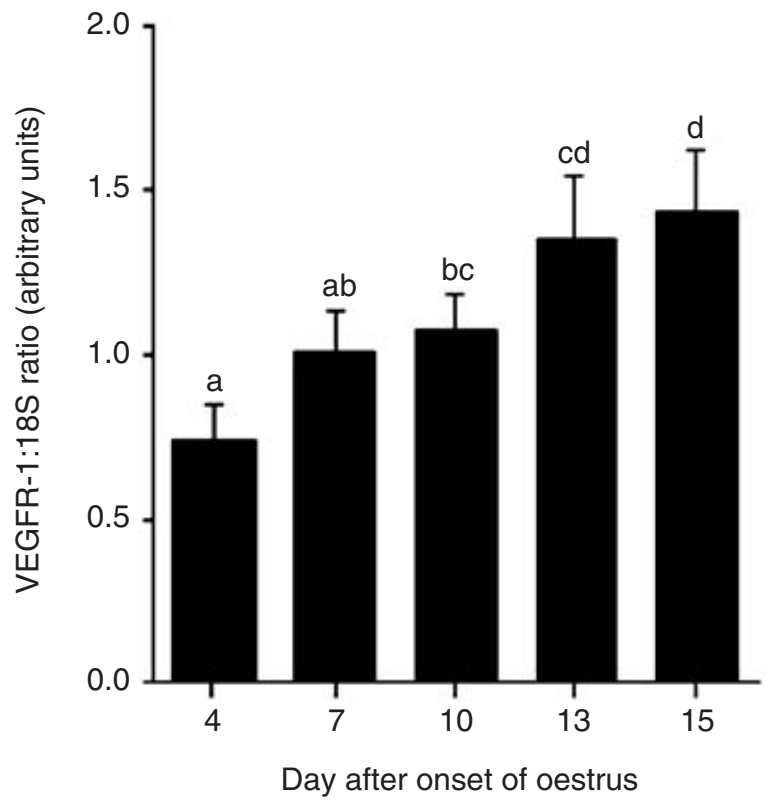

Fig. 2. Expression of vascular endothelial growth factor receptor 1 (VEGFR-1) mRNA in pig corpora lutea obtained at days 4, 7, 10, 13 and 15 after the onset of oestrus. (a) Representative autoradiograph of northern blot analysis for VEGFR-1 mRNA (top) and $18 \mathrm{~S}$ rRNA (bottom). VEGFR-1 mRNA size was approximately $7.0 \mathrm{~kb}$. (b) The relative amount of VEGFR-1 mRNA to $18 \mathrm{~S}$ rRNA (arbitrary units \pm SEM; $n=3$ animals day ${ }^{-1}$ ) differed between days. ${ }^{a-d}$ Values with different letters are significantly different $(P<0.05)$.

days $4-13$, but decreased significantly $(P<0.05)$ on day 15 (Fig. 3b).

\section{In situ hybridization}

High resolution examination of the cytospin slides by silver emulsion autoradiography indicated that the VEGF mRNA was localized primarily to large luteal cells (Fig. 4b). With the same technique for VEGFR-1 and VEGFR-2, large numbers of the small cell subpopulation also showed the hybridization signals (Fig. 4c,d).

The localization of hybridization signals of VEGF, VEGFR-1 and VEGFR-2 in luteal tissues obtained at day 4 after the onset of oestrus is shown (Fig. 5). The hybridization signals of VEGF within the corpus luteum 
(a)

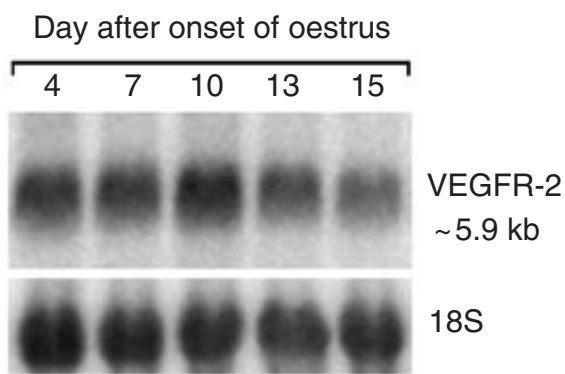

(b)

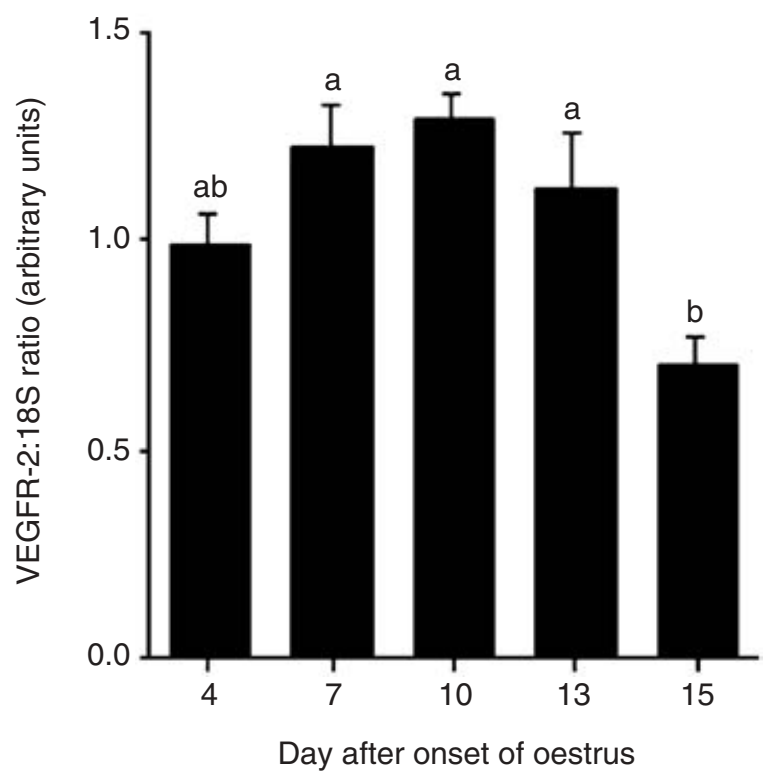

Fig. 3. Expression of vascular endothelial growth factor receptor 2 (VEGFR-2) mRNA in pig corpora lutea obtained at days 4, 7, 10, 13 and 15 after the onset of oestrus. (a) Representative autoradiograph of northern blot analysis for VEGFR-2 mRNA (top) and $18 \mathrm{~S}$ rRNA (bottom). VEGFR-2 mRNA size was approximately $5.9 \mathrm{~kb}$. (b) The relative amount of VEGFR-2 mRNA to $18 \mathrm{~S}$ rRNA (arbitrary units \pm SEM; $n=3$ animals day ${ }^{-1}$ ) differed between days.

${ }^{\mathrm{ab}}$ Values with different letters are significantly different $(P<0.05)$.

were localized in both large and small cells, but a more intense hybridization signal was observed over cells adjacent to the antrum (Fig. 5a,b). In early corpora lutea, hybridization signals for VEGFR-1 (Fig. 5c,d) and VEGFR2 (Fig. 5e,f) were observed primarily in the large cell compartment adjacent to the theca.

The localization of hybridization signals of VEGF, VEGFR-1 and VEGFR-2 in luteal tissues obtained at days 7, 10, 13 and 15 is shown (Fig. 6). In agreement with the results of northern blot analysis, in situ hybridization showed the expression of all three components of the VEGF in the corpus luteum at all days throughout the oestrous cycle.

Ovarian tissue with follicles was also collected for in situ hybridization to confirm the expression of VEGF,
VEGF-1 and VEGFR-2 in granulosa or thecal layers of follicles. The localization of hybridization signals of VEGF in ovarian tissues obtained at day 7 after the onset of oestrus is shown (Fig. 7). Non-specific hybridization used a ${ }^{35}$ S-labelled RNA sense VEGF strand (see Fig. $7 \mathrm{a}$ and $7 \mathrm{~b}$, bright- and dark-field, respectively). The hybridization signals of VEGF (antisense) were observed in the luteal tissue as well as in both granulosa and theca compartments of non-atretic follicles (Fig. 7c,d). The localization of hybridization signals in the follicular tissues obtained at day 15 after the onset of oestrus is shown (Fig. 8). Follicles were classified as healthy if granulosa cells were present on an intact basement membrane and as atretic if granulosa cells were detached from the membrane. Hybridization signals for VEGF and its receptors were visible in healthy follicles; however, in the atretic follicles, expression of neither VEGF nor its receptors was observed (Fig. 8b-d). When the expression of VEGF mRNA, which was evident in both compartments (granulosa and theca) of the follicular tissues (Fig. 8a,b) for comparison, was used expression of follicular VEGFR-1 and VEGFR-2 mRNA was limited to cells in a narrow zone between the granulosa and the theca compartment.

\section{Discussion}

In the present study, the expression of mRNA for VEGF, VEGFR-1 and VEGFR-2 in pig corpora lutea was demonstrated. The northern blot analysis of total RNA obtained from pig corpora lutea showed that there was hybridization of a single species of mRNA for VEGF. The VEGF transcript was approximately $3.9 \mathrm{~kb}$, corresponding in length to $\mathrm{VEGF}_{164}$. Other studies using RT-PCR have identified multiple VEGF transcripts in the corpora lutea (Redmer et al., 1996; Berisha et al., 2000); identification of a single transcript in the present study may be due to methodological differences. The cDNA clone used in the present study, which was approximately $415 \mathrm{bp}$, served as a template for the radiolabelled probe. On the basis of GenBank accession X81380 (Sharma et al., 1995), it is possible that the PCR strategy may have inadvertently excluded several nucleotides from exon 8 (Soker et al., 1997). As exon 7 is spliced out in the VEGF 120 isoform, it is possible that the probes may not have detected the $\mathrm{VEGF}_{120}$ isoform. Furthermore, in the present study northern blot analysis was performed with total pig corpus luteum mRNA and a short exposure time of $10 \mathrm{~h}$ in a phosphor imaging screen cassette, which may not have been sufficiently sensitive to detect other VEGF isoforms present at low concentrations in the preparations of corpus luteum RNA. However, the results of the present study did demonstrate the presence of $\mathrm{VEGF}_{164}$, the most mitogenic isoform (Soker et al., 1987), in pig corpora lutea. In addition, northern blot hybridization showed the presence of a single species 

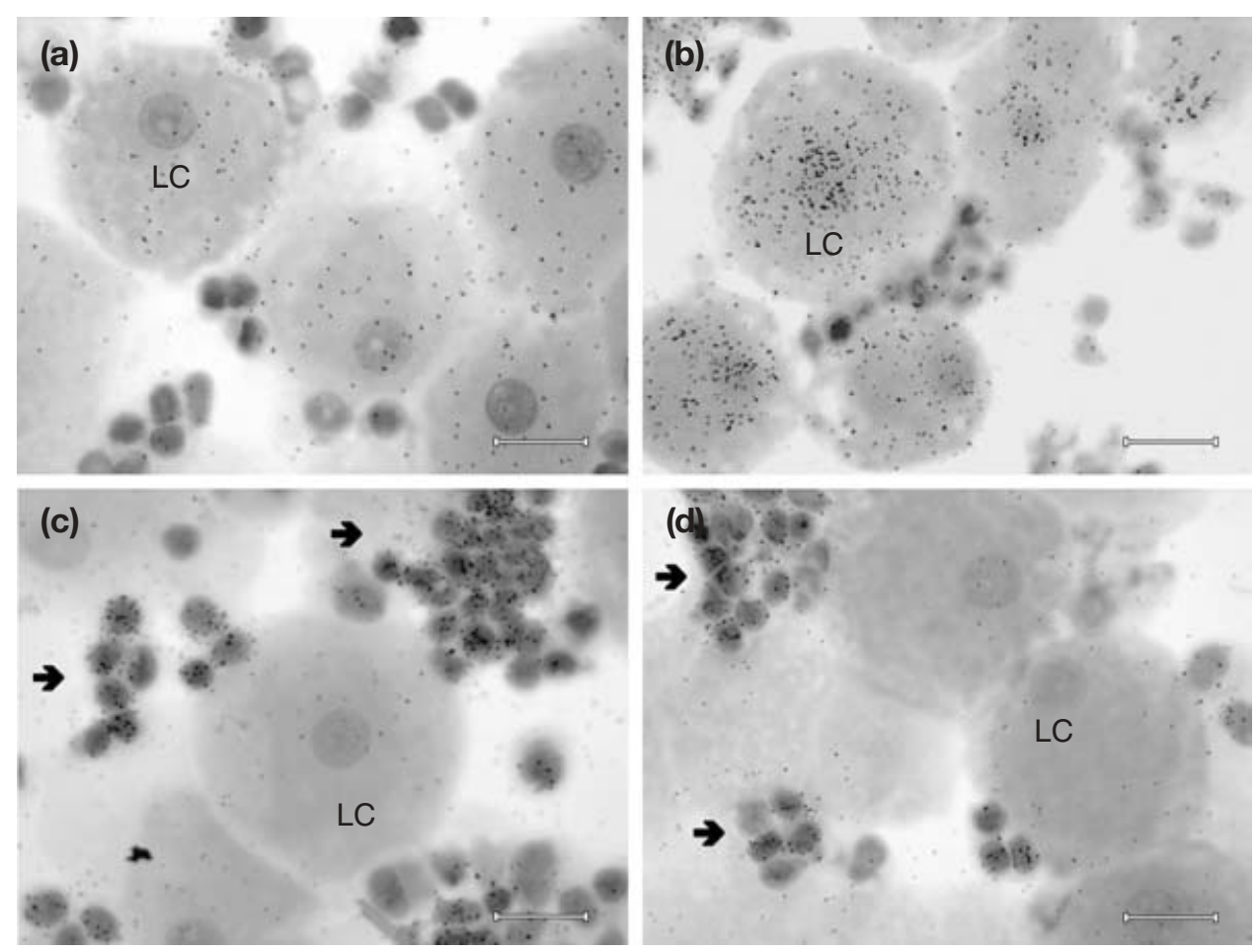

Fig. 4. In situ hybridization of vascular endothelial growth factor (VEGF), VEGF receptor 1 (VEGFR-1) and VEGFR-2 mRNA in pig luteal cells (cytospin slides) obtained from day 13 corpora lutea. In situ hybridization for mRNA encoding VEGF using the (a) sense and (b) antisense probes. In situ hybridization for mRNA encoding (c) VEGFR-1 and (d) VEGFR-2 using antisense probes. (b) Hybridization signals for mRNA encoding VEGF, seen as silver grains (black dots), are intense in large cells (LC). Hybridization signals for mRNA encoding (c) VEGFR-1 and (d) VEGFR-2 are present in most of the small cell subpopulation (arrows). Slides were stained with haematoxylin-eosin. Scale bars represent $20 \mu \mathrm{m}$.

of mRNA for both VEGF receptors. Major transcripts for mRNA for VEGFR-1 and VEGFR-2 were $7 \mathrm{~kb}$ and $5.9 \mathrm{~kb}$ in length, respectively.

The physiological differences, if any, between induced and spontaneous corpora lutea have not been thoroughly elucidated. Segal and Baker (1973) reported that corpora lutea are normal in structure and progesterone content on days 5 and 10 after gonadotrophin-induced ovulation in prepubertal gilts compared with spontaneously produced corpora lutea. In contrast, corpora lutea induced by administration of superovulatory doses of eCG (1000-1500 iu) and hCG (500 iu) to young gilts (aged 120-130 days) have increased susceptibility to uterine luteolysin (Puglisi et al., 1978), and a decreased sensitivity to gonadotrophins (Kineman et al., 1987). Recently, it was reported that differences in VEGF, Flt1 and Flk-1/KDR expression were evident between eCG- (1250 iu) induced follicles and spontaneously produced follicles in prepubertal gilts at 3 months of age (Shimizu et al., 2002). As a result of the conflicting reports on the differences between induced and spontaneous corpora lutea and follicles, it is difficult to substantiate or refute the contention that the VEGF ${ }_{164}$, VEGFR-1 and
VEGFR-2 mRNA content differs between the corpora lutea used in the present study and spontaneously produced corpora lutea.

VEGF mRNA was observed throughout the lifespan of the pig corpora lutea in the present study. Previous studies have indicated that the highest expression of mRNA for luteal VEGF is detected during the early luteal phase in other species (Ravindranath et al., 1992; Redmer et al., 1996; Berisha et al., 2000); however, there were no differences in the VEGF:18S rRNA ratio among the pig corpora lutea obtained from different stages of the oestrous cycle in the present study. The results are consistent with the recent report that expression of VEGF mRNA remained constant in human corpora lutea during the luteal phase (Sugino et al., 2000). Serum progesterone concentrations indicate that the corpora lutea obtained on day 15 were functional in the present study and, in agreement, the relative expression of mRNA for VEGF remained high on that day. However, a decrease in the amount of VEGF mRNA in the corpora lutea undergoing luteolysis has been reported (Ravindranath et al., 1992; Berisha et al., 2000; Sugino et al., 2000) and the relative amount of VEGF mRNA decreased in 

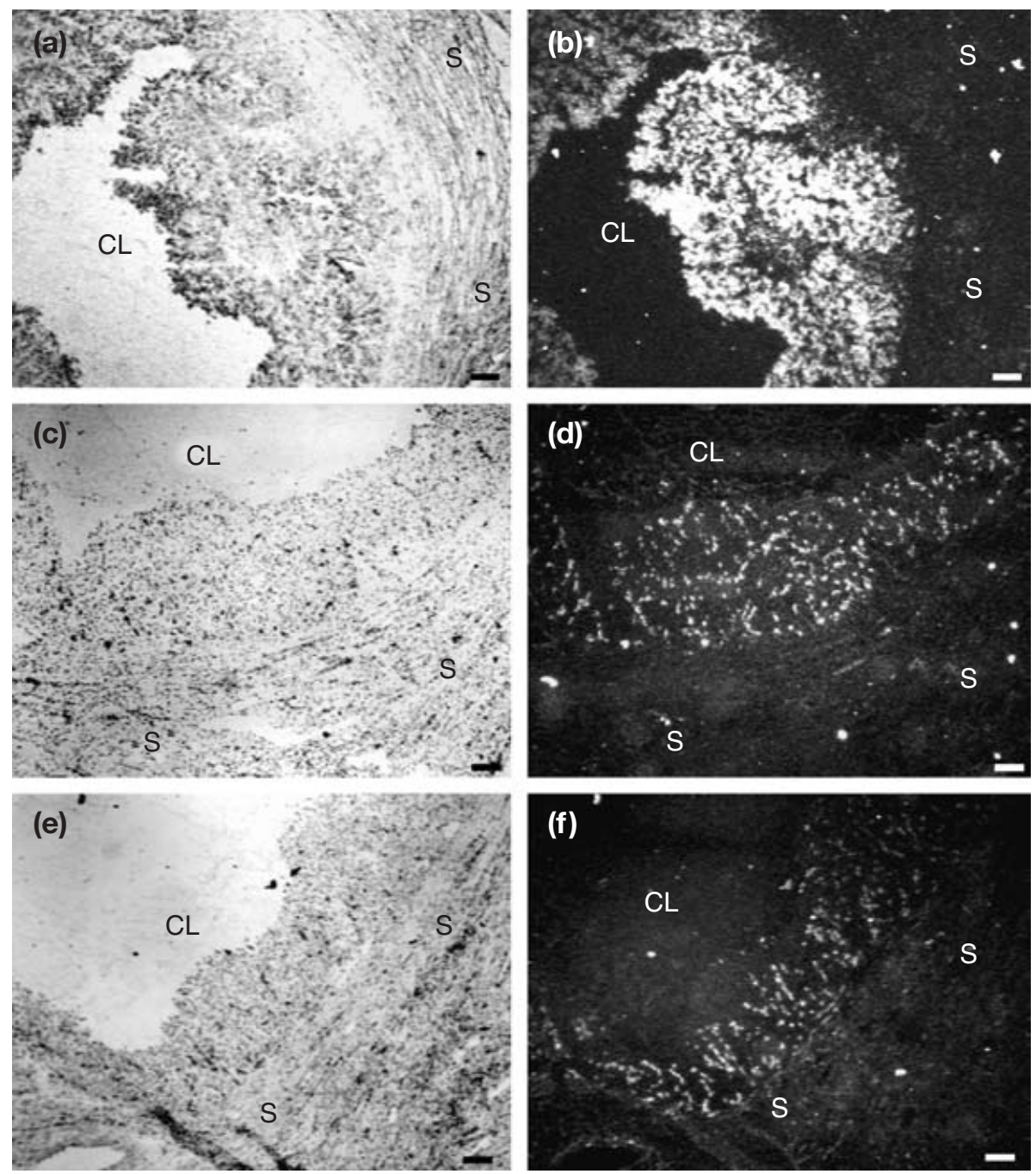

Fig. 5. Sections of pig ovary at day 4 of the oestrous cycle. $(a, c, e)$ Bright-field and $(b, d, f)$ darkfield images of hybridization using an antisense $(a, b)$ vascular endothelial growth factor (VEGF), (c,d) VEGF receptor 1 (VEGFR-1) or (e,f) VEGFR-2 RNA probe. (b) High hybridization signals for VEGF mRNA were observed predominantly in the granulosa-derived compartment, and higher intensity is localized in the area adjacent to the lumen of former antral cavity. Hybridization signals for (c,d) VEGFR-1 and (e,f) VEGFR-2 mRNA in the corpus luteum are visible in the granulosa-derived compartment, but higher intensity is observed in the area adjacent to the theca. CL: corpus luteum; S: luteal stroma. Scale bars represent $100 \mu \mathrm{m}$.

regressed corpora lutea in the present study (data not shown). Recently, $\mathrm{PGF}_{2 \alpha}$ was shown to have an inhibitory effect on the expression of the VEGF gene (Stocco et al., 2001), which would be consistent with this trend.

Although the expression of VEGF mRNA is consistent throughout the oestrous cycle until day 15, the expression of mRNA for VEGFR-1 or VEGFR-2 differed between the stages of the corpora lutea. Expression of VEGFR1 mRNA was relatively low at day 4 , but it gradually increased with age of the corpus luteum. An approximate twofold increase in mRNA expression was observed in the late luteal phase (day 15) compared with the early luteal phase (day 4). These findings differ from those reported for women (Sugino et al., 2000) and cattle (Berisha et al., 2000), in which expression of VEGFR1 mRNA was constant in the corpus luteum during the luteal phase. At present, there is not a clear explanation for this discrepancy, particularly in view of the debatable role of VEGFR-1 in angiogenesis. There is increasing evidence that VEGFR-1 may function as a decoy receptor for VEGF, thereby rendering this ligand less available to VEGFR-2 (Neufeld et al., 1999). Other data indicate that VEGFR-1 may play a role in vascular tube formation (Bussolati et al., 2001).

In the present study, the relative expression of mRNA for VEGFR-2 was increased during the early phase 

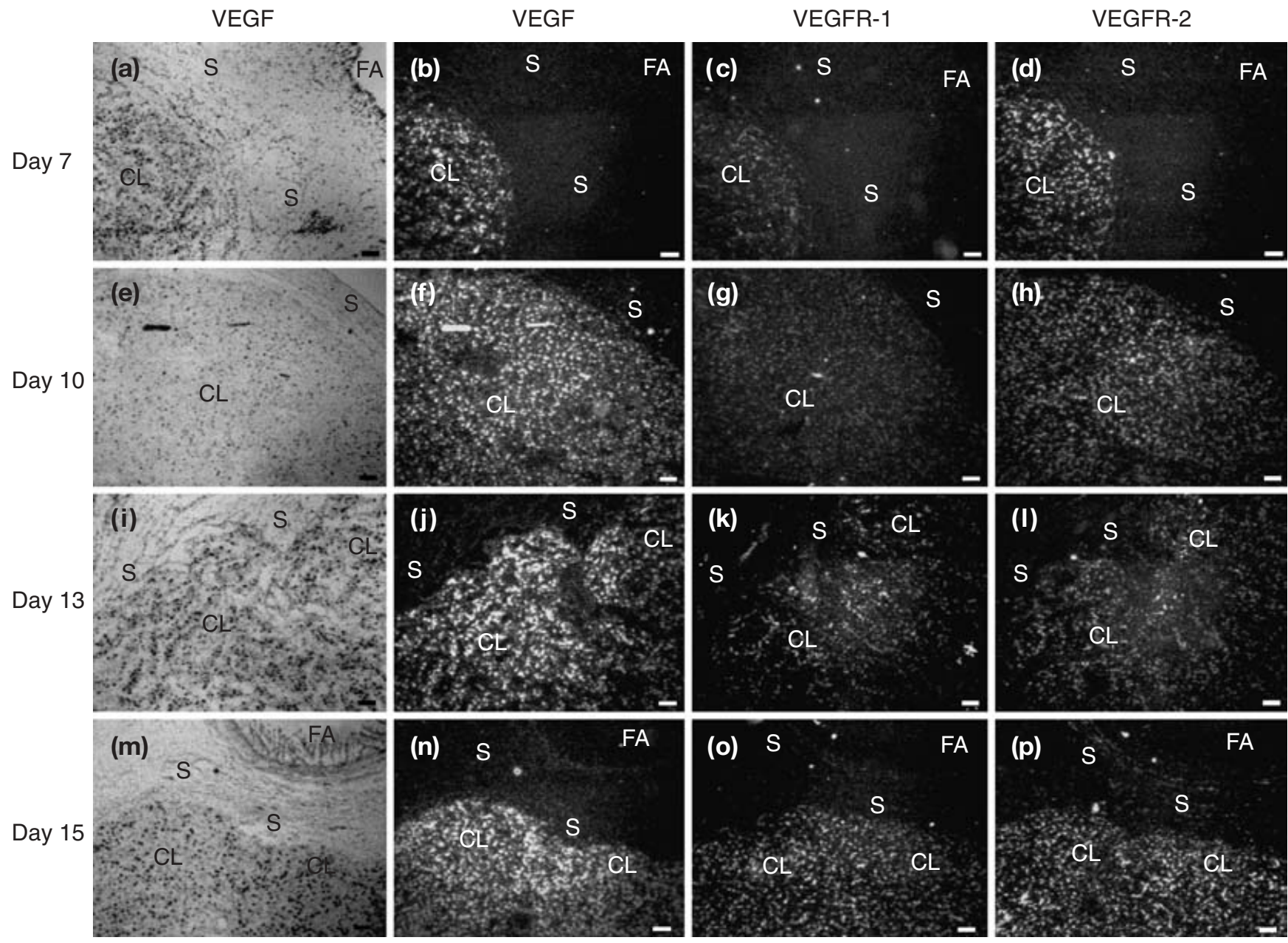

Fig. 6. Sections of pig ovary at days (a-d) $7,(e-h) 10,(i-l) 13$ and $(m-p) 15$ of the oestrous cycle. $(a, e, i, m)$ Bright-field and (b,f,j,n) dark-field images of hybridization using an antisense vascular endothelial growth factor (VEGF) RNA probe. Dark-field images of hybridization using antisense $(\mathrm{c}, \mathrm{g}, \mathrm{k}, \mathrm{o})$ VEGF receptor 1 (VEGFR-1) and (d,h,l,p) VEGFR-2 RNA probes. CL: corpus luteum; FA: atretic follicle; S: luteal stroma. Scale bars represent $100 \mu \mathrm{m}$.

(between day 4 and day 7), reached a peak at day 10 and remained high to day 13, before decreasing at day 15. Recently, a similar pattern was observed in bovine corpora lutea, in which the highest expression of VEGFR-2 mRNA was observed on days 3-4 of the oestrous cycle, followed by a decrease in expression during the midand late luteal phases (Berisha et al., 2000). The present observation of high expression of luteal VEGFR-2 during days $4-13$ of the oestrous cycle (compared with day 15 ) is consistent with the observation that high rates of cellular proliferation occur between day 2 and day 12 of the oestrous cycle in pig corpora lutea, and that most of the cell proliferation is endothelial cells (Ricke et al., 1999). As it is known that VEGFR-2 mediates the effects of VEGF on proliferation and migration of endothelial cells (Neufeld et al., 1999), and that VEGFR-2 is preferentially expressed by angiogenic endothelial cells (Millauer et al., 1993), the observations of the high expression of VEGFR-2 during the angiogenic phase of corpus luteum development and maintained concentrations of VEGF throughout the oestrous cycle are indicative of such a role for VEGF in pig corpora lutea.

These findings indicate that the difference in the pattern of expression of two different major types of the VEGF receptor may play a critical role in the regulation of the angiogenic effects of VEGF in pig corpora lutea. Although the expression of VEGF mRNA is consistent throughout the luteal phase, low expression of VEGFR-1 and high expression of VEGFR-2 at the early to midluteal phase may facilitate the extensive proliferation and migration of endothelial cells during the angiogenic phase. In contrast, when VEGFR-1 expression was at its highest on day 15, VEGFR-2 expression had decreased. These observations indicate that VEGFR-1 may attenuate VEGFR-2-mediated functions of VEGF, such that the actions of VEGF/VEGFR-2 are limited to the maintenance of luteal vasculature and prevention of intensive vascularization in the aged corpus luteum. 

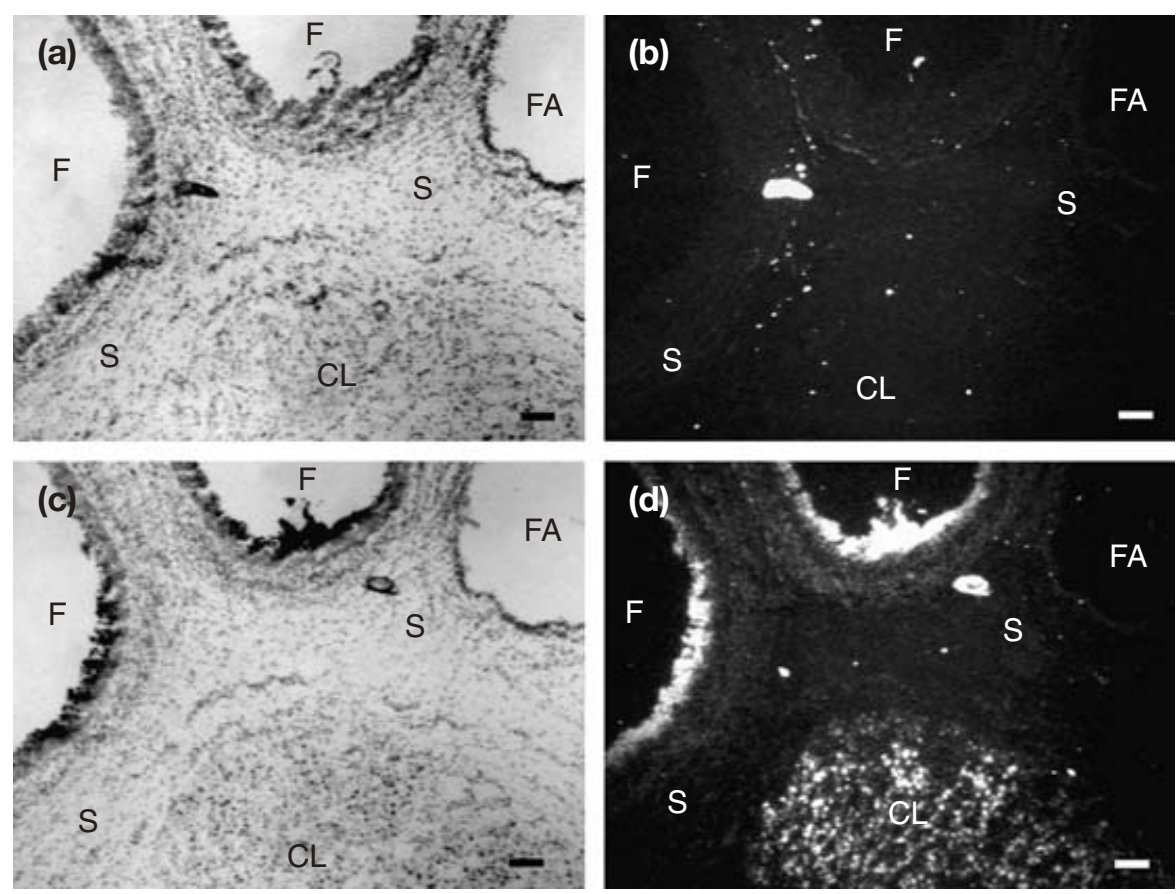

Fig. 7. Sections of pig ovary at day 7 of the oestrous cycle. (a) Bright-field and (b) dark-field images of hybridization using a sense vascular endothelial growth factor (VEGF) RNA probe (negative control). (c) Bright-field and (d) dark-field views of adjacent sections hybridized with an antisense VEGF RNA probe. High hybridization signals for VEGF mRNA are visible in the corpus luteum and mature follicle; however, the signal is absent in the atretic follicle. In mature follicles, hybridization intensities were higher in granulosa compartments than in the theca compartment. CL: corpus luteum; F: follicle; FA: atretic follicle; S: luteal stroma. Scale bars represent $100 \mu \mathrm{m}$.

In addition, increased expression of VEGFR-1 may be critical for VEGF-induced formation of vascular capillary tubes, which progress during the luteal phase in parallel with VEGFR-1 expression. Furthermore, expression of the mRNA encoding VEGF and VEGFR-2 in pig corpora lutea throughout the oestrous cycle also supports the hypothesis that VEGF is critical for endothelial cell survival and for sustaining vascular permeability of the corpus luteum (Dickson et al., 2001). However, additional investigations on protein concentrations and the function of the VEGF system in pig corpora lutea are needed to examine this hypothesis thoroughly.

Previous studies using RT-PCR indicated that both theca and granulosa cells of the antral follicles expressed VEGF; however, the granulosa cells responded to eCG stimulation with a progressive increase in expression of VEGF mRNA, whereas expression of VEGF mRNA in the theca compartment remained unchanged (Barboni et al., 2000). Studies using in situ hybridization of the ovarian sections obtained at day 15 after the onset of oestrus showed that both follicular compartments (theca and granulosa) expressed VEGF, and expression of VEGFR-1 and VEGFR-2 in the same follicles was also demon- strated. Follicles were classified as healthy (granulosa cells proximal to an intact basement membrane) or atretic (granulosa cells detached from the membrane). With this simple classification, expression of the VEGF system (VEGF and its receptors) was associated with healthy follicles, but neither expression of VEGF nor its receptors was observed in follicles that appeared to be atretic. Our results support a recent investigation, which used an ELISA technique to demonstrate that early atretic follicles had low or undetectable concentrations of VEGF in the follicular fluid (Mattioli et al., 2001). In healthy follicles, granulosa and theca layers expressed mRNA for VEGF, and the granulosa compartment had more intensive hybridization signals than did the theca compartment. However, the expression of mRNA for VEGFR-1 and VEGFR-2 was limited to a thin zone between the granulosa and the theca interna layer. This observation concurs with a previous report that the narrow zone $(0.03-0.04 \mathrm{~mm})$ between the granulosa and theca interna layers contains primarily endothelial cells and fibroblasts (Corner, 1919). The present finding, namely that the expression of VEGF, VEGFR-1 and VEGFR-2 is associated with healthy mature follicles, provides 

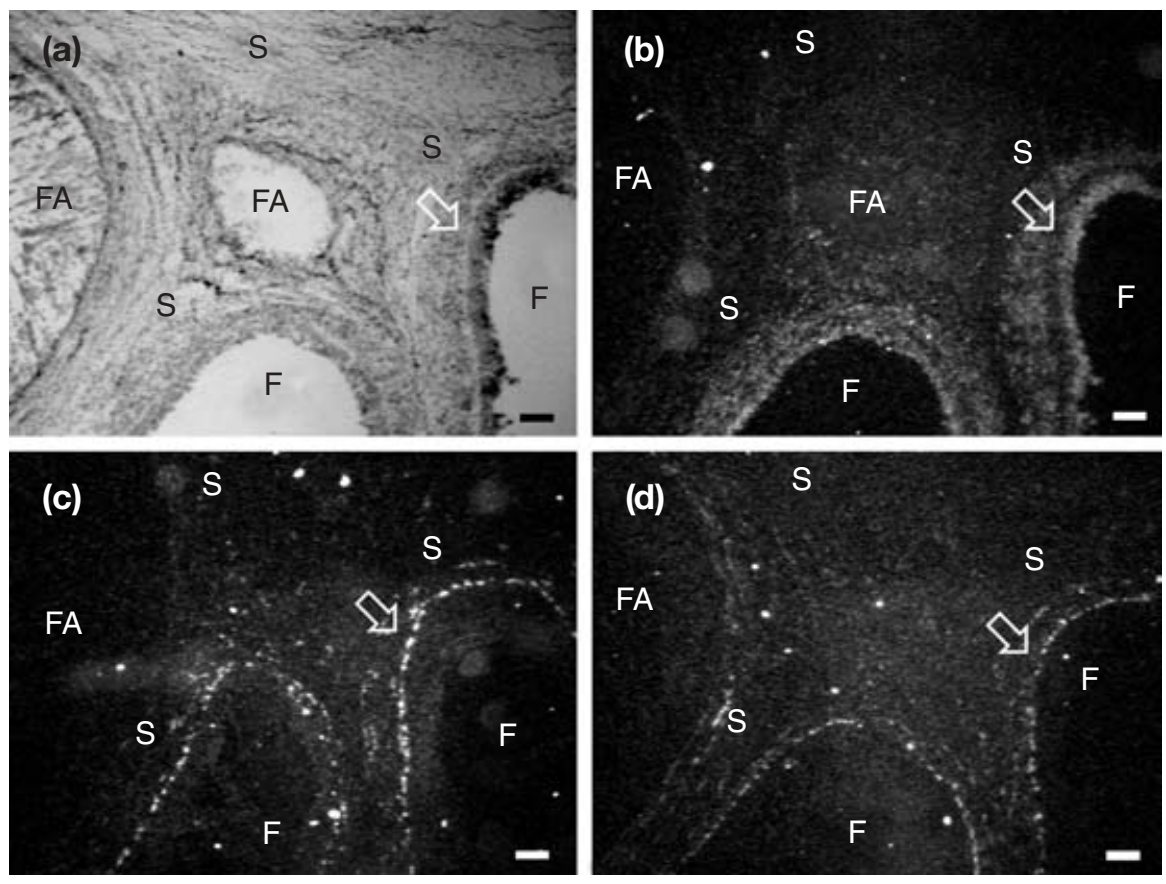

Fig. 8. Sections of pig ovary at day 15 of the oestrous cycle. (a) Bright-field and (b) darkfield images of hybridization using an antisense vascular endothelial growth factor (VEGF) RNA probe. (c,d) Dark-field images of hybridization using antisense (c) VEGF receptor 1 (VEGFR-1) and (d) VEGFR-2 RNA probes. Hybridization signals for VEGF mRNA in the follicular tissue were used as a control to observe the hybridization signals for VEGFR-1 and VEGFR-2 mRNA. Similar to VEGF mRNA, hybridization signals for VEGFR-1 and VEGFR-2 were not observed in atretic follicles. However, in mature follicles, hybridization signals for VEGFR-1 and VEGFR-2 were limited to a narrow zone between the granulosa and the theca compartments. CL: corpus luteum; F: follicle; FA: atretic follicle; S: luteal stroma. Arrows point to theca interna layer. Scale bars represent $100 \mu \mathrm{m}$.

support for a role of the VEGF system in angiogenesis, which accompanies follicular maturation and selection (Shimizu et al., 2002), and corpus luteum formation.

Although in situ hybridization of the early corpus luteum (day 4) clearly demonstrated expression of the VEGF in both granulosa-derived and theca-derived compartments, intensive hybridization signals for VEGF mRNA were observed in the granulosa-derived area adjacent to the lumen of the previous antral cavity. In contrast, the expression of mRNA for VEGFR-1 and VEGFR-2 was localized to the thecal layer. At high magnification, the expression of mRNA for both receptors was observed to be limited to small cells (data not shown). Corner (1919) reported that after the membrana granulosa breaks down, rapid sprouting and branching of the capillaries was observed throughout the entire granulosa and that these capillaries were apparently of thecal origin. Hence, the present results support the view that VEGFR-producing cells migrate from the zone between the granulosa and theca interna into the granulosa-derived compartment after ovulation. In addition, the data are in accord with the paracrine function of VEGF in angiogenesis of the corpus luteum (Redmer et al., 2001).

As shown by the northern blot analysis, the expression of the mRNA encoding for VEGF and its receptors was observed in sections of pig corpora lutea obtained from animals at all stages. The present findings using in situ hybridization of cells after cytospin preparation also indicate that the large luteal cell subpopulation expresses mRNA for VEGF, whereas the small cell subpopulation expresses mRNA for VEGFR-1 and VEGFR-2. The expression of mRNA for VEGF in the large luteal cells confirms an earlier report that the granulosa compartment is the primary site for VEGF synthesis (Barboni et al., 2000). In addition, it was found that some small cells obtained from day 7 corpora lutea expressed VEGF mRNA (data not shown), which is comparable to previous studies that showed pericytes as sources of VEGF in ovine corpora lutea (Redmer et al., 1996, 2001). In the present study, it is possible that the small cells are pericytes, which migrate with the endothelial cells 
during the vascular growth phase of the corpus luteum. Additional immunohistochemical evaluation with cellspecific markers was not performed in the present study to identify the types of cell in the small cell subpopulation that expressed mRNA for VEGFR-1 and VEGFR-2.

In conclusion, expression of mRNA for VEGF and its receptors in pig corpora lutea throughout the luteal phase was demonstrated in the present study, indicating a possible role for the VEGF system in the regulation of luteal angiogenesis and providing information on which to base future investigations on the role of VEGF system in corpora lutea of this species.

The authors would like to thank R. McNeel, Baylor College of Medicine, for the gift of cDNA for pig $18 \mathrm{~S}$ rRNA, and B. Peters, W. Flowers, C. Farin and W. Miller for their technical advice and support. This research was supported by the State Research Support program, NCSU College of Veterinary Medicine.

\section{References}

Augustin HG, Braun K, Telemenakis I, Modlich U and Kuhn W (1995) Ovarian angiogenesis. Phenotypic characterization of endothelial cells in a physiological model of blood vessel growth and regression American Journal of Pathology 147 339-351

Barboni B, Turriani M, Galeati G, Spinaci M, Bacci ML, Forni M and Mattioli M (2000) Vascular endothelial growth factor production in growing pig antral follicles Biology of Reproduction 63 858-864

Berisha B, Schams D, Kosmann M, Amselgruber W and Einspanier R (2000) Expression and tissue concentration of vascular endothelial growth factor, its receptors, and localization in the bovine corpus luteum during estrous cycle and pregnancy Biology of Reproduction 63 1106-1114

Boonyaprakob U, Gadsby JE, Hedgpeth V, Routh P and Almond GW (2003) Cloning of pig prostaglandin $\mathrm{F}_{2 \alpha}(\mathrm{FP})$ receptor $\mathrm{CDNA}$ and expression of its mRNA in the corpora lutea Reproduction 125 53-64

Bussolati B, Dunk C, Grohman M, Kontos CD, Mason J and Ahmed A (2001) Vascular endothelial growth factor receptor-1 modulates vascular endothelial growth factor-mediated angiogenesis via nitric oxide American Journal of Pathology 159 993-1008

Chomczynski P and Sacchi N (1987) Single-step method of RNA isolation by acid guanidinium thiocyanate-phenol-chloroform extraction Analytical Biochemistry 162 156-159

Corner GW (1919) On the origin of the corpus luteum of the sow from both granulosa and theca interna American Journal of Anatomy $\mathbf{2 6}$ 117-183

Dickson SE, Bicknell R and Fraser HM (2001) Mid-luteal angiogenesis and function in the primate is dependent on vascular endothelial growth factor Journal of Endocrinology 168 409-416

Ding ST, McNeel RL and Mersmann HJ (1999) Expression of porcine adipocyte transcripts: tissue distribution and differentiation in vitro and in vivo. Comparative Biochemistry and Physiology, Part B, Biochemistry and Molecular Biology 123 307-318

Farin CE, Moeller CL, Sawyer HR, Gamboni F and Niswender GD (1986) Morphometric analysis of cell types in the ovine corpus luteum throughout the estrous cycle Biology of Reproduction 35 1299-1308

Feng SM and Almond GW (1996) Identification and distribution of prostaglandin E receptors on porcine luteal cells Biology of Reproduction 54 1366-1374

Ferrara N, Chen H, Davis-Smyth T, Gerber HP, Nguyen TN, Peers D, Chisholm V, Hillan KJ and Schwall RH (1998) Vascular endothelial growth factor is essential for corpus luteum angiogenesis Nature Medicine 4 336-340

Fitzgerald MG and Hosking CS (1982) Cell structure and percent viability by a slide centrifuge technique Journal of Clinical Pathology 35 191-194
Fraser HM, Dickson SE, Lunn SF, Wulff C, Morris KD, Carroll VA and Bicknell R (2000) Suppression of luteal angiogenesis in the primate after neutralization of vascular endothelial growth factor Endocrinology 141 995-1000

Gadsby JE and Earnest KL (1994) Prostaglandin $F_{2 \alpha}$ stimulates progesterone secretion by porcine luteal cells in vitro throughout the estrous cycle Prostaglandins 48 109-125

Kamat BR, Brown LF, Manseau EJ, Senger DR and Dvorak HF (1995) Expression of vascular permeability factor/vascular endothelial growth factor by human granulosa and theca lutein cells: role in corpus luteum development American Journal of Pathology 146 157-165

Kineman RD, Rampacek GB, Kraeling RR, Fiorello-Stocks NA and Wilson RL (1987) Comparison of induced corpora lutea from prepubertal gilts and spontaneous corpora lutea from mature gilts: in vitro progesterone production Journal of Animal Science 64 526-532

Lei ZM, Chegini N and Rao CV (1991) Quantitative cell composition of human and bovine corpora lutea from various reproductive states Biology of Reproduction 44 1148-1156

Leung DW, Cachianes G, Kuang WJ, Goeddel DV and Ferrara N (1989) Vascular endothelial growth factor is a secreted angiogenic mitogen Science 246 1306-1309

Mattioli M, Barboni B, Turriani M, Galeati G, Zannoni A, Castellani G, Berardinelli P and Scapolo PA (2001) Follicle activation involves vascular endothelial growth factor production and increased blood vessel extension Biology of Reproduction 65 1014-1019

Millauer B, Wizigmann-Voos S, Schnurch H, Martinez R, Moller NP, Risau W and Ullrich A (1993) High affinity VEGF binding and developmental expression suggest Flk-1 as a major regulator of vasculogenesis and angiogenesis Cell 72 835-846

Neufeld G, Cohen T, Gengrinovitch S and Poltorak Z (1999) Vascular endothelial growth factor (VEGF) and its receptors Federation of American Societies For Experimental Biology Journal 13 9-22

Nicholson WC, Ge Z, Plotner DM, Farin CE and Gadsby JE (1999) Insulinlike growth factor (IGF)-I, IGF-I receptor, and IGF binding protein3 messenger ribonucleic acids and protein in corpora lutea from prostaglandin $F_{2 \alpha}$-treated gilts Biology of Reproduction 61 1527-1534

Phillips HS, Hains J, Leung DW and Ferrara N (1990) Vascular endothelial growth factor is expressed in rat corpus luteum Endocrinology 127 965-967

Puglisi TA, Rampacek GB and Kraeling RR (1978) Corpus luteum function following subtotal hysterectomy in the prepubertal gilt Journal of Animal Science $\mathbf{4 6} 707-710$

Ravindranath N, Little-Ihrig L, Phillips HS, Ferrara N and Zeleznik AJ (1992) Vascular endothelial growth factor messenger ribonucleic acid expression in the primate ovary Endocrinology 131 254-260

Redmer DA, Dai Y, Li J, Charnock-Jones DS, Smith SK, Reynolds LP and Moor RM (1996) Characterization and expression of vascular endothelial growth factor (VEGF) in the ovine corpus luteum Journal of Reproduction and Fertility 108 157-165

Redmer DA, Doraiswamy V, Bortnem BJ, Fisher K, Jablonka-Shariff A, Grazul-Bilska AT and Reynolds LP (2001) Evidence for a role of capillary pericytes in vascular growth of the developing ovine corpus luteum Biology of Reproduction 65 879-889

Ricke WA, Redmer DA and Reynolds LP (1995) Initial characterization of mitogenic factors produced by porcine corpora lutea throughout the estrous cycle Biology of Reproduction 52 Supplement $\mathbf{1} 112$

Ricke WA, Redmer DA and Reynolds LP (1999) Growth and cellular proliferation of pig corpora lutea throughout the oestrous cycle Journal of Reproduction and Fertility 117 369-377

Segal DH and Baker RD (1973) Maintenance of corporal lutea in prepubertal gilts Journal of Animal Science 37 762-767

Sharma HS, Tang ZH, Gho BC and Verdouw PD (1995) Nucleotide sequence and expression of the porcine vascular endothelial growth factor Biochimica et Biophysica Acta 1260 235-238

Shimizu T, Jiang J-Y, Sasada H and Sato E (2002) Changes of messenger RNA expression of angiogenic factors and related receptors during follicular development in gilts Biology of Reproduction 67 1846-1852

SAS (1988) SAS User's Guide: Statistics Statistical Analysis System Institute Inc., Cary 
Soker S, Gollamudi-Payne S, Fidder $\mathbf{H}$, Charmahelli $\mathbf{H}$ and Klagsbrun $\mathbf{M}$ (1997) Inhibition of vascular endothelial growth factor (VEGF)-induced endothelial cell proliferation by a peptide corresponding to the exon 7 encoded domain of VEGF165 Journal of Biological Chemistry 272 31 582-31588

Stocco C, Callegari E and Gibori G (2001) Opposite effect of prolactin and prostaglandin $\mathrm{F}_{(2 \alpha)}$ on the expression of luteal genes as revealed by rat cDNA expression array Endocrinology 142 4158-4161

Sugino N, Kashida S, Takiguchi S, Karube A and Kato H (2000) Expression of vascular endothelial growth factor and its receptors in the human corpus luteum during the menstrual cycle and in early pregnancy Journal of Clinical Endocrinology and Metabolism 85 3919-3924

Wandji SA, Wood TL, Crawford J, Levison SW and Hammond JM (1998) Expression of mouse ovarian insulin growth factor system components during follicular development and atresia Endocrinology 139 5205-5214
Wulff C, Wilson H, Rudge JS, Wiegand SJ, Lunn SF and Fraser HM (2001) Luteal angiogenesis: prevention and intervention by treatment with vascular endothelial growth factor trap (A40) Journal of Clinical Endocrinology and Metabolism 86 3377-3386

Zimmermann RC, Hartman T, Bohlen P, Sauer MV and Kitajewski J (2001) Preovulatory treatment of mice with anti-VEGF receptor 2 antibody inhibits angiogenesis in corpora lutea Microvascular Research 62 $15-25$

Received 21 February 2003.

First decision 15 April 2003.

Revised manuscript received 29 May 2003.

Accepted 9 June 2003. 